\title{
Experiments in Industrial Democracy: An Historical Assessment of the Leicestershire Boot and Shoe Co-operative Co-partnership Movement
}

\author{
Peter Ackers, Department of HRM, De Montfort University, Leicester, UK
}

\begin{abstract}
State-socialist academics have been highly sceptical of worker co-operatives. Following the Webbs' classic studies, they assume that capitalist market competition renders them either inefficient or undemocratic. The experience of the British co-operative co-partnership (COCP) movement, from the late nineteenth to the early twenty-first century, suggests a more optimistic reading, with implications for future alternative forms of work organization. COCP worker co-operatives were long-lived and participative, while advancing other social goals, such as good wages and working conditions, union membership and better housing. This article introduces the theory of COCP, stressing the stakeholder model and the predominance of employee representatives. Next, I establish Leicestershire as a major regional centre for both shoemaking and COCP, linked to the wider institutions of consumer co-operation. Six co-operatives are discussed: three Leicester city societies, Equity, Anchor and Self-Help; and three village societies, Barwell Sperope, Glenfield Progress and Sileby Excelsior. The article concludes that footwear COCP was a relatively successful small-scale endeavour, not subject to the fatal contradictions predicted by the Webbs. The movement died out because the bureaucratic 'spirit of the age' in the British co-operative and wider labour movement, turned against these initiatives from below, which therefore failed to rejuvenate.
\end{abstract}

Key Words: Industrial Democracy, Co-operative Co-partnership, Worker Participation, Worker Co-operatives, Footwear, Leicester, Sidney and Beatrice Webb, State-socialism.

\section{Introduction}

Arguably, the little-known co-operative co-partnership (COCP) movement was one of Britain's most significant experiments in industrial democracy and alternative forms of work organization. Drawing upon the ideals of Robert Owen, Christian socialism and radicalliberalism, these COCPs were led by working men and combined a large measure of worker control with independent trade unions. They offered a small-scale, partial alternative both to conventional capitalist ways of organizing industry, and the emerging, twentieth century state-socialist panaceas of bureaucratic consumer co-operation and centralized state ownership. As small businesses, they were long-lived compared to their private equivalents, and deeply embedded in the larger consumer co-operative movement; demonstrating the importance of support from a larger institutional network. While I touch upon economic 
criteria, my main concern here is with the COCP social mission, expressed in the experience of their workers and the surrounding local community. Some degree of business success is a necessary condition for this, but by no means a sufficient one. Thus a COCP which met standard business economic expectations, but jettisoned all social goals in the process, must be adjudged a failure. While, one that underperformed (as many small conventional businesses do) by normal commercial criteria, yet remained afloat and met the social objectives of its members, might be considered a success.

This leads us away from accountancy measures of worker co-operative success and failure, to ask more qualitative questions of these experiments in industrial democracy. Inside the workplace, how far did they maintain trade union rights, good wages and conditions, opportunities for worker participation and a satisfying working environment? Beyond the workplace, what was their contribution to the wider community? Here, I subject the longstanding theoretical debate over the relative merits of worker co-operatives, as a general form of democratic business organization, to the specific historical experience of the Leicestershire boot and shoe COCPs. First, the COCP model is located within the history of British cooperative theory and practice, contrasting the sympathetic view of the early pioneers towards worker self-management with the more hostile stance of the Co-operative Wholesale Society (CWS), as this entered large-scale production in the late nineteenth century. This consumer co-operative model was most powerfully endorsed by Sidney and Beatrice Webb. Next, I turn to the formation and progress of COCP within the Leicestershire footwear industry, where its impact was deepest and most lasting. After that, we trace six case histories. Leicester Equity opened first, became the largest and traded until 2009, while Leicester Anchor pursued the most ambitious social goals. The other four are sketched briefly to illustrate the range of local 
characteristics, so that, by the end, we reach a composite picture of the achievements and potential of the COCP model.

\section{Co-operative Co-partnership in theory and practice ${ }^{1}$}

It is a strange fact that most of the promoters of the Consumer Co-operative Movement were, during the second half of the last century, more concerned with the role of workers than that of consumers. ${ }^{2}$

Producer co-operation was an integral part of the original British co-operative ideal, yet as consumer co-operation became the dominant national model, a sharp ideological divide emerged between those 'idealists' who advocated a democracy of producers and the 'practical' proponents of a democracy of consumers. During the twentieth century, the triumph of the Rochdale consumer model acquired an air of inevitable historical progress, much as utopian socialism was superseded by modern, 'scientific' state-socialism. The very mention of these examples today, testifies to the historical fragility of such conventional wisdoms. The victors may write the history of the past in their own image, but only until such a time as their victory itself comes into question. Hence, post-Communist doubts about the past appeal and future viability of state-socialist solutions have revived interest in voluntary, co-operative models. While, at the same time, the very crisis of contemporary British consumer co-operation, as both a commercial project and an ethical ideal, affords new opportunities to re-examine some of these lost experiments. With all the great left-of-centre twentieth century paradigms disputed and in crisis, perhaps these 'little utopias', created from below, have something to offer historical and contemporary debates about community and civil society? ${ }^{3}$ But, first, let us recapture that Victorian debate.

The strongest intellectual supporters of worker participation in the co-operative movement were the early Christian socialists, followed by those radical-liberals who became architects 
of the COCP movement. Each group argued that without active worker participation cooperation would lose its spiritual heart and degrade into bureaucracy. Workers should be given sovereignty and control within the productive sphere, as well as the first call on profits; an ethical view grounded in a labour theory of value. Moreover, worker participation would engender good workplace relations, and, hence, contribute to higher business efficiency. So consumer control should be restricted to the sphere of distribution. The first attempt to put this ideal into practice were the short-lived, self-governing workshops of the 1850 s, including 'several boot and shoe making co-operatives' with union support. ${ }^{4}$ The second wave of producer co-operation in the 1860s and 1870s embraced a wider range of investors, including consumer co-operatives, trade unions, individual middle-class idealists and workers, and began to exhibit a more stakeholder pattern of ownership and control. These initiatives also failed, but the need to marry worker participation with external investment funds and consumer co-operative links created the germ of the COCP model. By this stage, however, the highly successful consumer co-operative movement was losing patience with its penurious partner, and in 1873 the Co-operative Wholesale Society (CWS) itself expanded into production. This move was resisted by radical-liberals who believed that all co-operative production should be conducted by COCPs that gave their workers a share in management and profits. Initially, the CWS acceded to an annual employee bonus, but abandoned this in 1875, and from 1886 onwards rejected all such notions, while massively expanding production along conventional business lines.

The Co-operative Productive Federation (CPF) was founded in 1882, with 126 affiliates, in direct response to the (partial) defeat of the worker participation ideal within the mainstream consumer co-operative movement, and became the representative body for COCP. It acted as a trading agent and propagandist for its associated societies in relation to both the wider co- 
operative movement and the general public. In addition to representing the collective will of COCP, the CPF aimed to open markets for the sale of their goods and to obtain investment capital. The Labour Co-partnership Association (LCA), founded two years later, in 1884, was another reaction to the defeat of the $\mathrm{COCP}$ within mainstream co-operation. Also based in Leicester, the LCA held a broader and looser propaganda brief to spread the gospel of copartnership in industry, not only through producer co-operatives, but also through worker shareholdings and bonus schemes in conventional, capitalist business organisations.

Although each COCP member of the CPF has its own constitutional peculiarities, the basic model was as follows. ${ }^{5}$ All members or shareholders have one vote, no matter how much share capital they hold, and they elect the management committee. Represented on this are members employed by the society, individual members not so employed, and other cooperative societies that are also members. This raises the complication that usually not all members are workers and sometimes not all workers are members. No member has any right to employment, though in practice societies endeavoured to employ as many members as was commercially possible. The General Manager is appointed by the Management Committee which exercises a stronger oversight than a normal company Board of Directors. Net profits are devoted first to a 5\% dividend on shares, followed by some further division between workers, customers, shareholders, educational and providential funds. Usually workers can't take their share of the profits in cash until they have accumulated the requisite sum in the shares of the society. It is clear from this brief outline that the COCP co-partnership didn't amount to a straightforward workers' ownership, as in standard worker co-operatives. Rather it represented a stakeholder model of corporate governance, offering the workers a substantial share in profits, at least a place on the board, and, in many versions, majority control. 
Beatrice Webb's (then Potter) 'ruthlessly logical' ${ }^{6}$ analysis of the CPF statistics for 1890 , found only 8 self-governing workshops from 54 producer societies. This depiction of the of the inevitable choice between economic and social failure - 'phantom' participation - has shaped thinking ever since. Her trenchant critique of the fledgling COCP movement followed the dominant CWS professional management view of JTW Mitchell and others. Accordingly, worker-controlled societies were few, feeble and doomed to either economic or social failure. In the first case, workers would interfere with management, lack discipline and thus render the business uncompetitive. In the second, they might succeed only by becoming closet, semi-capitalist societies which pursued their own selfish interest at the expense of other producer co-operatives and other workers. Thus the Webbs championed the more socially responsible federal consumer model against the selfish individualism of producer cooperation. In this light, the expansion of the CWS into production - even its takeover of former worker co-operatives - was a wholly welcome development, consistent with the forward march of democratic consumer sovereignty. Ever since, the Webbs have furnished state-socialists with some of the standard arguments to be deployed against worker cooperatives. Even Marxist writers sympathetic to workers control have joined them in the deterministic argument that the encircling market will inevitably degrade these islands of workplace democracy ${ }^{7}$ - an argument the Webbs didn’t apply to consumer co-operation.

The other face of the Webbs' negative analysis is their future-orientated, state-socialist normative preference for a management planning bureaucracy presided over by middle-class experts; a view which later attracted them to Soviet Communism. As Harrison points out, the Webbs' take on co-operation is part-and-parcel of their ideological architecture or 'the tripartite conception of labour movement'. Thus it suited their emerging political strategy to see co-operation as the consumer arm of the movement, with trade unions as the producer arm 
and the Labour party as the political arm. Producer co-operatives muddied the water.

Moreover, while Beatrice,

recognised the moral excellence of collective self-help...Her opposition to co-operative production depended upon convictions about the efficient organisation of business and not upon hostility to self-management as such. Democratic collectives might replace capitalists; but she denied that they could dispense with the services of professional experts. ${ }^{8}$

As we shall see, COCPs didn't dispense with specialist managers. While the Webbs' pioneering, empirical social science analysis deserves to be taken seriously, their dismissal of COCP is partly rooted in political bias.

Indeed, Jones argues that the 'Webb's ideological stance impaired their objectivity and that as a result their data were misleading and inadequate'. ${ }^{9}$ First, he points to the serious difficulty in defining and measuring the success of 'producer co-operation'; a term which embraced a spectrum of organizations, from the wholly owned subsidiaries of the CWS, with no participatory elements, to full-blown self-governing workshops. None of the available sources of information, from the CPF, LPA or Co-operative Union (CU), adequately encompass or disaggregate these diverse businesses in such a way that the historical rise and fall of genuine COCPs can be easily traced. Following careful analysis of the available data, Jones identifies five periods. Their pre-history, up to 1882 , takes in the two early experimental and unsuccessful waves, discussed above. Next, from 1882 to 1893 , the CPFs development of a COCP model saw an 'incredibly dynamic phase'. Legitimate worker-led cooperatives increased more than six-fold and the movement remained 'vigorous' until 1918. The inter-war period was one of the stagnation in which 'the expansionary momentum generated during the third period was not sustained'. The final period, since the Second World War - until producer co-operation revived in the 1970s outside the established cooperative movement - saw 'one set-back after another'. 
Jones sets this historical pattern against the Webbs' claims. As early as 1895, Beatrice had written the obituary of British COCP, a theme she returned to with her husband, Sidney, in 1921, insisting that: 'All such associations of producers that start as alternatives to the capitalist system either fail or cease to be democracies of producers'. ${ }^{10}$ Ironically, it was between these two dates that, according to Jones, the largest and most sustained surge of producer co-operation took place. During this period, COCP spread to a wide range of cooperative business activity and secured trading relationships with mainstream consumer cooperation; thwarting any claims of isolationism. As we shall see, this institutional embeddedness was particularly characteristic of Leicestershire boot and shoe COCPs. Moreover, the Webbs' economic prognosis was suspect too. Far from bring 'ill-adapted to survive', ${ }^{11}$ COCPs outlasted many private businesses of a comparable size, as worker cooperatives continue to do.

The Webbs' major alternative hypothesis was that these businesses survived only by shedding the last vestiges of their democratic identity. To their credit, they tried to gauge the level of participation according to the proportion of the management committee that were employees, using CU returns for 1890 and 1913. They then labelled the producer co-operatives as selfgoverning, partially autonomous or dependent on the stores. Reapplying the same method, Jones suggests that they both misinterpreted the situation that existed when they wrote and the direction of development. In fact, participation, by their measure, had increased markedly between 1890 and 1913, and continued to do so until the mid-1950s, 'more and more societies were becoming self-governing'. This suggests the more participative societies were also the most resilient and commercially successful. Jones' reinterpretation of the statistics and exposure of 'the Webb's startling misrepresentation' of COCP re-opens a firmly bolted door and calls for further evidence and analysis. ${ }^{12}$ However, there are obvious limitations to an 
aggregate quantitative approach, in terms of measuring the number of COCPs, and of evaluating the level of participation within them. As Jones recognises, neither the longevity of co-operatives nor the number of workers on the management committee provide an adequate, rounded picture of either economic success or worker participation. Both cry out for more detailed historical accounts of actual COCPs. Moreover, internal participation is not the only measure of the social impact of a COCP. They also had potential benefits for union membership, for the standard of wages and conditions, and for local employment. Once more, these can only be explored through local case-studies. ${ }^{13}$ The Leicestershire boot and shoe industry provides an interesting regional and sectoral picture of $\mathrm{COCP}$ in action for a century or more.

\section{The Leicestershire Boot and Shoe Co-operative Co-partnerships ${ }^{14}$}

It can be said that as Manchester is the centre of the Consumers' Co-operative Movement, so Leicester is the centre of the Producers' Co-operative Movement. ${ }^{15}$

The location of the two national COCP organizations in Leicester was a telling choice. The city was a long-standing centre for radical-liberal, religious dissent and politics, dominated by two industries: hosiery and footwear. By 1890, the National Union of Boot and Shoe Operatives (NUBSO) 'was the dominant working-class organization in Leicester with a virtually all-male membership, organized in two branches whose combined total was 12,000 workers'. Moreover, leadership of the NUBSO was passing from old-style Liberals, who favoured arbitration to a new generation of radicals and socialists, led by T.F. Richards, for whom worker co-operatives were a central element of union strategy. ${ }^{16}$ Three elements came together to create this favourable environment for COCP: skilled male workers facing the transition to larger-scale factory boot and show production; an expanding consumer cooperative movement that eventually bridged the consumer/ producer divide; and a local 
radical religious and political ferment that drew local NUBSO activists into the national COCP movement.

By end of the nineteenth century, Leicestershire had become the main national centre for women's and children's shoes, and in 1925 was second only to Northamptonshire as a footwear centre, with a quarter of British output. ${ }^{17}$ However, the industry was a late developer, beginning in the 1850 s. Only in the 1890 s, did the transition to steam power approach completion, as the system of village sub-contracting fell into disuse and modern factory production expanded rapidly. By 1892 NUBSO pressure had ensured that less than $5 \%$ of workers in the city were employed 'outdoors'. However, the NUBSO's skilled male 'laster' elite were ambivalent about large-scale factory production and hostile to deskilling by new footwear technology. This group of skilled, respectable and self-improving men formed the nucleus of the new COCPs. The industry remained small scale at the enterprise level, such that in 1950 of the county's 57 firms, 38 had less than 100 workers and only 11 over 250 . One company, the BUSMC, enjoyed a virtual monopoly of machine making and its preferred system of tied leasing kept small manufacturers viable. Altogether, these industrial characteristic aided the emergence and survival of the local footwear COCPs. From the late 1880 s, they joined an expanding industry still completing the transition to modern manufacturing and particularly open to craftsmen with small amounts of capital. Soon growth stalled and industrial relations broke down in the 1895 lock-out. Nevertheless, the slow pace of mechanisation, the machinery leasing policy, and the importance of fashion in the women's shoe market, all provide a favourable environment for the birth and growth of the boot and shoe COCPs. 
The second element was an expanding local consumer co-operative movement. The Leicester Co-operative Society (LCS) was founded in 1860. Boots and shoes were basic needs of the working classes, so by 1872 there were moves 'to promote co-operative production in the boot and shoe trade'. ${ }^{18}$ A nascent footwear co-operative already had 120 members and $£ 150$ in capital when the CWS supported the purchase of a factory in Dun's lane. On 15 September 1873, CWS manufacturing began at West End Shoe Works, Leicester. The factory was extended in 1876 and 1884, and in 1891 the CWS opened the brand-new Wheatsheaf Works, at Knighton Fields with a capacity of 50,000 pairs per week. By 1898, this factory was 'undoubtedly the largest in England', producing 1,500,000 pairs a year of 'Wheatsheaf Brand' to the value of $£ 317,000$, with between 400 and 500 women in the closing room alone. Employment increased from 420 in 1876 to 1,295 in 1890 and 2,249 in $1890 .{ }^{19}$ Equity would emerge from a dispute at this factory, and there were early tensions, but in the long-run COCP benefitted from the strength of the local consumer movement and close political and commercial links to it. For by 1890, LCS had 7,000 members and a turnover of $£ 200,000$, with departments for groceries, drapery, boot and shoe, coal, butchery and furniture, plus a co-operative corn mill. It grew rapidly between 1890 and 1914, tripling membership to over 14,000 and raising turnover to over $£ 530,000$. Here was a ready-made and growing market and while before 1914 CWS produced up to half of all these goods, other local producer cooperative, included COCPs, provided $2 \% .{ }^{20}$ Thus the consumer model became dominant, but supportive of local COCPs, with a key figure, Amos Mann, 1908 President of the LCS.

But why was the workers control idea so strong and resilient in Leicester? Most of the late nineteenth century societies apparently, 'sprang directly from the workers themselves'. ${ }^{21}$ And the six Leicestershire COCPs discussed below were part of a broader movement for producer co-operation, centred on NUBSO and industrial relations tensions, including the 1895 
national shoe lock-out. Lancaster sees a 'transition from working-class Liberal to socialist politics', with mechanisation breaking 'the ideology of self-help liberalism shared by both master and men'. He has 'the waning of the co-operative ideal' as early as the 1895 lock-out, to be displaced by municipal socialism. ${ }^{22}$ This seems schematic and raises a number of issues centred on loose and ambiguous meaning of 'socialism' in this English context. Worker cooperatives had deep roots in the radical-liberal shoemaking tradition, while the main industrial consequence of the lock-out was an exemplary liberal-pluralist system of national collective bargaining that lasted until the death of the industry. As Fox concludes, 'We can now see that it was they [the liberal-pluralists] who were in the main stream of social and political development, not the Socialist militants'. ${ }^{23}$ Biagini and Reid point to the close and overlapping relationship between Victorian radical-liberalism and twentieth century British ethical socialism. ${ }^{24}$ I too find continuity rather than rupture, with the radical-liberal social philosophy of COCP proving highly resistant to a state-socialism that became fashionable after the First World War.

Indeed, a brief prosopography ${ }^{25}$ of local and national COCP figures suggests a voluntarist faith that drew from a deep well of secular Owenite communitarian and religious nonconformist religious ideas about self-help and self-improvement, grounded in much older NUBSO traditions of craft and radicalism. We'll meet many of these people below. Alongside 'socialists' in the Independent Labour Party (ILP), such as Martin Curley (Equity), Alice Hawkins (Equity), TF Richards (Self-Help), JT Taylor (Equity and Anchor), we find Liberals like JH Brewin (Glenfield Progress), John Potter (Equity) and more ambiguous Lib-Lab figures, such as Charles Eagle (Equity), Amos Mann (Anchor) and J. Stanton Salt (SelfHelp). Many were religious nonconformists or secularists, and the close relationship between Taylor and Mann below suggests a 'progressive' alliance. And while working men drove the 
local initiatives, the COCP model was drawn from three leading national, radical-liberals Edward Greening, George Holyoake and Henry Vivian - all with craft backgrounds and roots in a tradition of religious dissent and secularism - as a deliberate counter to state-socialism. ${ }^{26}$ As Lancaster concedes, 'existing societies in Leicester were already heavily influenced by the Neale-Greening school of co-operation... Thus the socialist co-operators of the early $1890 \mathrm{~s}$ had to work within an existing ideology'. ${ }^{27}$ As we shall see, this radical-liberal influence would extend well into the twentieth century.

Thus a collision of new industrial and social trends and older working class ideas lay behind the remarkable late Victorian boom in Leicestershire COCPs. In 1889, there were nine cooperative productive societies in Leicester, and between 1880 and 1893 'thirty-odd' were established nationally. ${ }^{28}$ Leicester COCP extended well beyond the boot and shoe industry to include a large printing society, a society of carriage builders and wheelwrights, and the Wigston hosiery society. Statistical evidence places Leicester footwear at the vanguard of COCP, whether we consider the number of co-operatives or the level of worker control within them. In national terms, boot and shoe co-operatives constituted at least a third of all genuine COCPs (the aggregate figures in Table One include many more questionable organizations), and the largest single industrial grouping. The average footwear management committee had an $80 \%$ employee representation, about a third of shares and membership was in the hands of employees, and more than $70 \%$ of workers had become members. ${ }^{29}$ Cole records that in 1938 of 1,881 footwear workers involved nationally, 1,461 were members; while $87 \%$ of all COCP sales went to consumer societies; and the CWS produced boots and shoes to twice the value of all the footwear COCPs. Table One suggests a general decline of COCP from 1920 onwards, but while Cole has CPF affiliates fall from 44 in 1923 to 41 in 1938, the number of employees actually rose, from 5,200 to $8,200 .{ }^{30}$ 
- Table 1 here -

More serious decline commenced after the Second World War. Even then, however, footwear COCPs, especially those in Leicester, fared considerably better than the rest of the movement. The six main businesses, discussed below, were already well-established by 1922, and by 1927 they had been joined by a short-lived newcomer, New Era of 44 Causeway Lane, Leicester. However, by 1940 this had closed, as had one of the original six, Leicester Anchor. The Second World War witnessed a sudden but transient growth in shoe repair co-operatives and by 1951 there was another short-lived arrival, J.J. Footwear. Overall then, there was no lasting addition to those COCPs formed in the last two decades of the nineteenth century and the first of the twentieth, while the original six remained in business between 42 and 117 years. Now let us now explore these in greater depth.

- $\quad$ Table 2 here -

\section{Leicester Equity (1887 - 2009) $)^{31}$}

Equity provided the new model, whose general principles others footwear COCPs would follow. It was the earliest of the societies considered, easily the largest, and the only one to survive into this century. The society was formed on 16 and 17 September, 1886 by Leicester and Enderby shoe workers from the Wheatsheaf CWS works, in reaction to the strike there. According to Lancaster ${ }^{32}$, outsourcing and new machinery were issues, along with the authoritarian style of the CWS manager, John Butcher, which offended the workers 'cooperative principles' of wanting more voice and a share of the profits. Significantly, the leading Liberal co-operator, Edward Greening, was asked to draw-up the COCP constitution. Over 200 workers invested and by 1890 Equity employed 170 workers. Profits were divided 
as follows: $35 \%$ to workers, $20 \%$ to customers, $15 \%$ to share capital, $12 \%$ to the committee, $10 \%$ to a provident fund and share capital, $5 \%$ to a social and educational fund, and $3 \%$ to pay members for specials services. The workers' share was retained throughout Equity's history, though the contribution to customers grew to more than match this. Overall, the founders had three goals: a fair share in profits, industrial peace and a large degree of self-management. In 1904 C. Webb declared, 'the workers control the society and have always elected practically all the committee'. ${ }^{33}$ But this would prove the most difficult and controversial goal over the next century.

Nevertheless, the vision of an alternative employment relationship was central to the concept of Equity; shortened from the original, 'Liberty, Equality, Fraternity'. Business began in a small way with four workers and $£ 420$ in capital provided by them, a few sympathisers and the NUBSO. By late 1889 , membership had risen to 500 and an education department had been formed. In 1895 Equity employed 280 workers, had a turnover of $£ 38,390$ and capital of $£ 16,622$. The society continued to grow rapidly, and in 1895 it had 992 members, and had raised output to 88,642 pairs. On 16 April of that year, George Holyoake, the leading national co-operative thinker, opened the new, larger factory capable of housing 500 workers. In 1897 membership passed 1,000 and by 1898 Equity employed between 300 and 400 workers with 50 women outworkers. The business suffered in the early decades of the twentieth century and by 1926 employment had fallen to 166 . The initial product were high-quality men's boots, but eventually Equity forged a specialist niche for high class women's shoes and by 1936 employment had recovered to 398. In 1936, the market remained almost exclusively cooperative stores, as a matter of principle, excepting some expedient cash purchases. But from 1957 the company dropped the co-operative name, to become just 'Equity Shoes' - freeing itself from the declining co-operative retail market - so that by $196940 \%$ of sales were to the 
private sector. As Table Two shows, Equity enjoyed twice the membership of Anchor and four or five times that of other societies and thus generated more capital, making for a stronger business organization. When Equity closed in January 2009, making 98 workers redundant (and creating a pension crisis), it was lamented as Leicestershire's last major footwear manufacturer. ${ }^{34}$

Equity also began with large social ambitions. The top floor of the new Bede Works in 1889 housed a large hall, seating 250 , for educational and social uses, with a library, newspapers, games, a piano and picture of leading co-operators. Building societies were formed and high quality workers housing was built nearby. In this way, Equity became a symbol for the emerging labour movement and many local political activists worked there. By the inter-war years, the social activities had broadened into entertainment, including billiards, cycling, swimming, dancing, whist drives and a football team. No one doubts that Equity became a good place to work, but was it more than that? Greening's earliest 1898 account depicts a business 'free from the harass of strikes and lock-outs', which paid full union rates and never had cause to make employees redundant, 'whether times have been good or bad'. ${ }^{35}$ In 1927 Howles found its management committee entirely composed of members working in the factory as well as one ex-employee. ${ }^{36}$

But in truth, there were arguments between 'workers control' and management prerogative from as early as the $1880 \mathrm{~s}$, and after World War One direct control drifted upwards from the shop-floor to professional management. By 1936, Plumb noted a 'decline in co-partnership ideals' in the wider society, while calling for larger political anti-capitalism. ${ }^{37}$ Yet, "'Equity" is a tiny haven of refuge, a foretaste of socialist method, in a capitalist world'. Writing in 1971, Kirkham also recognises the 'working-class Non-conformist values...thrift and 
caution', as central to Equity longevity, but charts a growing bureaucratization of management control, leaving the business as just another good employer. ${ }^{38}$ In 1986, Pepper (President and past Manager/ Secretary for many years) reported that all employees and some other members still elected the Board. Until 1960 they'd elected the Secretary and Manager too, a position now appointed by the Board, and Pepper concludes with words that might please the Webbs:

much of the day-to-day running of the business has now passed to the Society's expert paid officials, the Board retaining overall control. ${ }^{39}$

\section{Leicester Anchor (1893-1935)}

Anchor COCP represents a highly distinctive instance of a working class religious community creating their own miniature Jerusalem, in an 'experiment' by 'a body of working men' to work-out 'their own industrial salvation, on the lines of the co-partnership of workers'. ${ }^{40}$ Six years after Equity, Anchor blended still more expansive co-operative principles with a pragmatic business opportunity. According to Amos Mann, in 1892 J.T. Taylor, an Equity member and employee, had the idea of a nursery shoe manufacturing society also organized as a COCP. ${ }^{41} \mathrm{He}$ called a meeting of men interested in the children's trade at Crafton Street Church of Christ, a radical protestant sect to which both he and Mann belonged. Most of those present at the founding meeting were chapel members, as were the majority of workers in the early days of the new COCP. The new venture was supported nationally by the CPF and CU, and locally by the LCS and Equity. Good relations continued between the two societies, which Taylor continued to straddle. Both men were on the first eight-strong committee, with Taylor as President. From May 1887, Mann became a foreman in the riveting department, until he left the factory to work in a full-time propaganda role for the LCA in April 1912. 
Mann and Taylor are fascinating figures, who personify the type of working class figures leading the new COCPs. Mann (1855-1939) was an NUBSO autodidact who became a Churches of Christ preacher and temperance advocate. Already active in the LCS at Equity's formation, he was President 1908 to 1936 and on the central board of the CU from 19221936. He became a leading national co-partnership figure before the Second World War, sitting on the 1914 Co-operative Congress inquiry committee and from 1911 served as President and Secretary of the LCA and as a national propagandist for co-partnership. Politically, he was elected as a Liberal to Leicester Town Councillor from 1877 to 1908 and seems to have retained a broad Lib-Lab progressive perspective. Taylor (1864-1957) stayed closer to the ground, working for the CWS, Equity and then Anchor, where he became Secretary and long-term manager. He was the key force behind the Anchor Housing COCP, where he led the new Churches of Christ chapel. Ostensibly more 'socialist' to begin with, as ILP treasurer and councillor for Wyggeston, he worked closely with Mann to provide leadership in the overlapping religious and COCP communities. Between them, these two men embody all the key elements of the emerging local labour movement: religious nonconformity, the NUBSO, producer and consumer co-operation, and lib-lab and the ILP traditions on the local council.

Anchor's initial economic development followed a similar pattern to Equity. The first premises, a back-street workshop, opened in March 1903, and two years later the original manager left after difficulties with a 'committee composed of workers', to be replaced by Taylor, who also became Secretary. ${ }^{42}$ Some months before, Taylor had resigned as President because he felt his membership of the Equity management committee led to a clash of interests. However, in June 1895, he moved to work at Anchor as its first traveller. Thus one of the perennial problems of COCP - the confused relationship between employee rights and 
management prerogative - had arisen, but been resolved at an early stage by the choice of a manager in tune with both priorities. Mann assumed the mantle of President, and for many years they jointly led the co-operative. Another characteristic early bone of contention was the men's attitude to labour-displacing and deskilling technology. ${ }^{43}$ As we have seen, COCP was especially alluring for craftsmen - clickers and lasters - protecting their jobs and skills. Most late Victorian shoe factories were little more than workshops of hand shoemaking, using rudimentary machinery. This gave an initial ease of access to the industry, but by the turn-ofthe-century, mechanisation was transforming the industry, and the first move of premises by most COCPs, including the Anchor factory extension of 1910, was accompanied by a substantial investment in new machinery.

At this point, the social goal of COCP shifted from handcraft values to the preservation of employment in the process of technical change, something facilitated by the early buoyancy of shoe trade. After some early efforts in the open market, Anchor traded almost exclusively with co-operative stores. Trade doubled over the next five years, leading to further mechanisation and, in the spring of 1898, the opening, by the city's mayor, of a new, purposebuilt factory in Asfordby Street, New Evington - indicating a broad political appeal. By then the original membership of 40 had grown to 250 . Business suffered in the first decade of the new century, but revived in the years before the Great War, enabling a further extension in 1910 for an up-to-date making plant. In 1914 Mann foresaw a 'bright' future for the cooperative, but it ceased to trade in late $1935 .{ }^{44}$ Yet, in 1927 Anchor had broadened its original children's market to include both the 'Fultred' brand for children and the 'Clef' brand for women. Howles reports a favourable coverage in the British Industries Review for their 'excellent management', 'quality production' and 'good treatment' of employees. ${ }^{45}$ 
While Anchor was the most short-lived society, it had the most ambitious social programme. The co-operative was constituted along radical COCP principles, whereby all workers must become members with $40 \%$ of net profits going to their wages. The policy that worker members could not cash their profits and interest until they had a share capital of $£ 100$ meant that by 1927 workers held nearly $£ 10,000$ of capital. The factory adhered strictly to trade union conditions, and in 1897 Anchor took pride in shortening the working day from 54 to 49 hours.

Hours of labour are naturally an important matter in co-partnership workshops, for we not only strive for share of profits and management, but to use those advantages to secure better conditions all round. ${ }^{46}$

The following year, Anchor introduced one week annual paid holiday for all workers (rescinded in harsher economic times). Moreover, the social mission extended well-beyond worker participation and profit-sharing. There was an active education policy led by Mann to inculcate co-operative ideals into the workforce. Between 1900 and 1913, there were as many as nine lectures a year, including one from Philip Snowden and three from Ramsay MacDonald, the Labour MP for Leicester and a future Prime Minister. ${ }^{47}$ Mann himself conducted a dozen lectures, and in 1906 Taylor spoke on 'Direct Representation in parliament'. ${ }^{48}$

Another 1902 speaker was the ubiquitous, Henry Vivian, on 'Economics and the Working Man' and, most influentially, 'Co-operation and the Housing of the People'. ${ }^{49}$ His vision was quickly translated into a COCP garden suburb, outside Leicester, for Anchor workers to live in. This followed Robert Owen's community-building visions, the ideals of Ebenezer Howard's garden city movement - Letchworth, the first garden city opened in 1903 - the practical example of enlightened paternalists and the rules of Vivian's Co-partnership Tenants Association, established in 1905, with Vivian, Greening and Howard, and the employers, 
Lever and Cadbury, on the executive. Their consulting architect, Raymond Unwin, designed the Anchor estate. So once again there was a wider progressive movement, with cross-class links. Over 40 housing COCPs were formed between 1901 and 1922, one by a South Wales miners lodge ${ }^{50}$ During 1902, 45 Anchor workers, including Taylor and Mann, began to subscribe to the project, raising $£ 500$ over the next five years. A Professor Timson had lectured to the members in 1904 on 'The Garden City a Solution to the Housing Problem', and preparatory visits were made to Bournville and Port Sunlight. Initially, they planned a new Anchor factory at the heart of the project, but some of the existing workforce resisted the idea, and they settled for a purely residential estate. In 1907 they purchased 48 acres of land at Humberstone, then an entirely rural area outside Leicester, but within walking distance of the tram terminus, and began to build their garden suburb. The aim was to apply COCP principles to housing, provide workers' houses with gardens and create an idyllic working class residential community to rival those enjoyed by the better-off.

Taylor and Mann were city councillors in 1907 and they convened an impressive public 'demonstration' on the estate. This was addressed by the Chairman of Birmingham Housing Committee (1901-11) and the Association of Municipal Corporations, the Liberal Unionist/ Independent Councillor, John Nettlefold, a vociferous opponent of statist municipal council housing and advocate of planned garden suburbs and COCP tenants associations. ${ }^{51}$ Henry Vivian MP chaired a 'large number of prominent Leicester citizens', including the city mayor. Another former mayor, Alderman Sir John Wood, came too as leader of the Leicester Liberal Association and a supporter of the 1906 pact with Labour. ${ }^{52}$ Once more, the presence of leading progressive Liberals is notable, as is the influence of voluntarist, radical-liberal models of urban development. Taylor and Mann sought the widest support and the first development of 69 houses was opened in October, 1908 by Lady Rolleston. The work was 
carried out by the COCP's own direct labour arm, to a specification of only seven to eight houses to the acre; building semi-detached houses with gardens for workers. By 1914 there were 94 houses and building was proceeding on a further ten acres. On the mature estate, there was a large open space with fruit trees, allotments and lawns, as well as a bowling green, tennis court, shops, a Churches of Christ chapel and an institute. Birchall records a 'Central block with 3 shops/ office/ meeting room/ recreation room'. ${ }^{53}$

In Mann and Taylor's minds, a community needed a place of worship, as they and other Anchor workers moved out of Leicester to populate the estate. This third overlapping spiritual circle, linking work and housing to make community, was the Christian Meeting House, which opened in 1910. In the absence of other local religious institutions, this became a community church for the garden suburb with a substantial Sunday school and its own holiday home. According to Forrester, the Churches of Christ's Sabbath rules and puritanical attitudes generated predictable tensions in a mixed community. 'The sect provided the moral tone for the whole community', but this proved 'difficult to live up to...[and] many feel alienated from their Meeting House' ${ }^{54}$ Today the estate has been engulfed by council housing and modern private estates. Forrester has the 'utopian period' lasting from 1907 to 1914 , to be swept away by the social change of two world wars and the sprawl of Leicester into the intervening countryside. But also by municipal power, which led to the compulsory purchase of the garden suburbs and allotments, ruthlessly severing the original pastoral vision. In the 1930s, co-partnership appeared old-fashioned, if not moribund; co-operation had been swallowed up in state socialism. ${ }^{55}$

Anchor provided stable, well-paid employment, under trade union conditions for a substantial workforce over a forty year period; no mean economic achievement. Apart from Anchor's contribution to the welfare of its workforce, some of the founders' broader social aims 
survived in the pleasant, decent housing they created. With exception of a few very large paternalists, such as Clark, Cadbury, Rowntree or Lever, few conventional businesses can claim such a legacy. ${ }^{56}$

\section{Leicester Self-Help (1896-1970)}

This was the society most directly associated with the Leicester NUBSO. While other COCPs included union activists, recognised the union, and in some cases benefited from union shareholding, here the NUBSO played a still more active role. Founded in May 1895, in direct response to the great national boot and shoe lock-out, this COCP was established by workers from the failed St. Crispin Boot and Shoe co-operative, which too had been supported and financed by the local NUBSO branch.

Several working men, trade unionists, were determined to help themselves, if possible, by the starting of a properly constituted Co-operative Society, believing that was the only way to secure fair conditions of labour. It seemed practically impossible for them to secure work in the boot societies already established, so many were waiting for employment, that even with reasonable expansion it would be years before others could hope to be put on to work. Many found themselves thrown out of employment through the introduction of machinery, which was then being rapidly applied to boot making, and which, by new inventions, was becoming very efficient. ${ }^{57}$

Three Leicester public figures, Councillor Edwards, Alderman Flint and Alderman Wood secured a loan for the society from the bank, and the last donated $£ 100$. NUBSO union officials, including T.F. (Freddy) Richards, a future national union President, played a key role in its early development, while Equity and Anchor also gave support.

In economic terms, the early society struggled and did not return a half-year profit until June 1907. Like the others, Self-Help commenced business on a small scale, first in Willow Street, Leicester, before moving, in March 1898, to a larger factory in Gower Street, Belgrave Gate, to introduce new production methods into the finishing and closing departments. In an appeal for further capital, they received aid from the Leicester NUBSO No. 1 and No. 2 branches as 
well as other friends. The cost of moving and problems with workers adapting themselves to new methods put the society in the red again. However, they soon returned to profit, and in 1909 they moved again to a new, purpose-built factory at Dartford Road, Aylestone Road, on the south side of Leicester. On this occasion, they borrowed money from the Leicester consumer society. Only then, did Self-Help complete the transition from hand methods; some indication of the cost and soul searching this entailed. Three years before, a Mr Bodicoat became manager, and like his counterpart at Anchor, he was still in this position in 1927. By

1914 , the society had returned a record turnover of $£ 14,000$ p.a., capital of $£ 3,500$ and a halfyearly profit of $£ 380$ (June, 1914), and record trade was anticipated. The Self-Help constitution adopted the model of the Co-operative Union, which made all shareholders eligible to the management committee. However, in 1915 most were workers in the factory. COCP status seems to have continued after 1954 when the name changed to Toy Town Shoes, which closed in March 1970.

\section{Barwell Sperope (1891-1965)}

The shoemaking village of Barwell, with a population of 3,000 in 1915, was at the heart of the boot and shoe area around Hinckley, on the border of Leicestershire and Warwickshire.

Shoemaking was of such local importance that the union had a branch office in the village well into the 1980s when the local official could walk me round several factories. Over the years, there were 24 factories in the town, according to one recent, unsourced account: ${ }^{58}$ The Barwell Productive Society was founded as a cooperative in 1890, in a small yard off High Street, known as Piccadilly. The workers put down $£ 5$ each to start the firm, after a secret meeting held at night behind the rifle butts on Burbage Common. It was run as a cooperative with Mr Wilf Harvey as the first chairman of the Management Committee. In 1895 it was renamed the Sperope Boot Manufacturing Company and moved to Kirkby Road. The name is derived from the Latin meaning Expect and Hope. The company made small orders which were not financially viable and was taken over in the late 1960's by George Ward (Barwell). 
Consumer co-operation in Barwell dated two decades earlier. Sperope's first year saw a turnover of $£ 5,925$, capital of $£ 490$ and a loss of $£ 6.10$ s.6d. By 1895 trade had increased sufficiently to justify the construction of a new factory, a total cost of $£ 1,784$. In introducing machinery at this stage, Sperope was in advance of other footwear COCPs. By the end of 1913 , the society had attained a turnover of $£ 23,118$ and share capital of $£ 3,068$. Like Anchor, Sperope was fully integrated into the wider co-operative movement through its Manager and Traveller, Mr Hincksbut:

This Barwell society has shown the possibility of entering successfully into the ordinary competitive market, for while paying good wages and conforming to good conditions they have been able to obtain some portion of their trade outside the Co-operative movement. ${ }^{59}$

In 1927 Sperope seemed 'one of the most promising' societies, both on account of the 'finish and style of its goods' and 'the way in which the business is worked'. The society played an important social role in village life by creating manufacturing employment to keep the rural community alive and by producing local public figures.

\section{Glenfield Progress (1892-1968)}

This was another village society, situated in Glenfield, 3 miles outside Leicester, with a population of 1,000 in 1915 . The society was first formed in 1892 by a group of shoemakers assisted by 'several prominent members of the local distributive society'. ${ }^{60}$ This 'co-op village' was a microcosm of the distinctive Leicester combination of consumer, productive and housing co-operation. The Progress pioneers had $£ 90$ of capital, when the business commenced in January 1893, and for the first year turnover was $£ 1,700$ leading to a small loss of $£ 40$. The initial impetus was village unemployment, and after early losses, the society grew rapidly during its first decade of life. A new Station Road Factory was built in 1895 and two years later power machinery was introduced and the working week cut to $52 \frac{1}{2}$ hours. In 1901 the local consumer and productive societies merged and by 1913 had 247 members and 
employed 90 workers. For the half-year of June 1914, turnover had reached £10,240 creating a profit of $£ 531$.

The success of this society is all the more remarkable when it is known that quite a good few of private individuals have endeavoured to establish boot and shoe businesses in the village but have failed. ${ }^{61}$

The original manager and Secretary, Mr Brewin was still in office twenty-one years later, when he received a special watch, as a symbol of his good relations with the workers.

Birthday celebrations were shared with Anchor at the Grand Hotel in Leicester, with Mann and Taylor speaking. The latter argued, in true nonconformist style, that 'from a financial standpoint Co-partnership had been a success, but a better test of its worth was seen in the building up of the character of the workers'. The society maintained the radical version of COCP principles, and in 1915, as a matter of policy all the management committee, save one, worked in the factory. As with Sperope, Progress helped to revitalize village employment and life. 'This is surely an instance of how a village population can be kept at home, and how the blending of rural life with manufacturing activity can be brought about'. ${ }^{62}$ Brewin chaired the Parish Council too, while the 1914 President was Secretary of the local Liberal Association and active in the Adult School movement. Like Anchor, the society also became involved in workers' housing, creating another, 'Garden village, affording to the workers the change of allotment or other kinds of garden in their daily employment'. ${ }^{63}$

\section{Sileby Excelsior (1906 - after 1957)}

Excelsior was formed a decade later than the other COCPs in the shoemaking village of Sileby, between Leicester and Loughborough, as a manufacturer of girls' and women's footwear. ${ }^{64}$ In 1901, this industrial village had a population of 3,082, with a brick and tile works, a brewery, six hosiery factories and six boot and shoe factories. The stimulus was 
'poor conditions of labour' and the aim 'to better their position and to raise the standard of labour', but they faced serious opposition:

The arrangements for commencing the Society had to be carried out in a secret fashion owing to the resolve of the boot manufacturers of the district to frustrate their efforts. These employers agreed to boycott the workmen who were suspected of having any connection with this new movement. If connection was suspected they were instantly dismissed from their employment: sixteen workmen were actually stopped. ${ }^{65}$

Members contributed $£ 10$ in share capital to rent a two-storey factory and start production in December 1906. Although they lacked business experience, Excelsior made good headway and at the end of the first year turnover was $£ 2,593$, yielding a $£ 70$ profit. Over the next two years, trade doubled to $£ 7,640$ in 1909 . By then the existing premises were too small and a new factory was built opposite, at a cost of $£ 1,159$, with money borrowed, predictably, from the LCS. Production commenced here in December 1910, when turnover was $£ 9,582$, and by 1914 this had risen to $£ 22,190$, with a profit of $£ 918$. By 1927, Excelsior had a substantial, modern factory near the railway station and served a growing trade. As a late starter, the cooperative seems to have avoided the early adverse trading of other COCPs, and in its first twenty years increased its turnover from $£ 2,500$ to $£ 70,000$.

Excelsior made a dual contribution to the village economy, by providing not only jobs, but by building union membership and collective bargaining. All the workers joined the local NUBSO, greatly strengthening a branch which had: 'Failed to make any impression upon the Sileby workers, the manufacturers of that district being bitterly opposed to organised labour'. ${ }^{66}$ Here the COCP carried labour movement employment values out of the urban centres into a small, non-union village, which later housed the NUBSO district 'Unity Hall'. As Percy Whittington, a future union representative, recalled:

They were dead against trade unionism in Sileby for some time. But the Excelsior shoe factory, they started off...I became out of work in $1921 \ldots$ off and on for about six months, and I got a job eventually with Excelsior...it was compulsory for me to join the trade union, then... So I joined the trade union...' ${ }^{67}$ 


\section{Conclusions: Co-operative Co-partnership - a suppressed historical alternative? ${ }^{68}$}

There are some obvious historical limitations to the Leicestershire footwear COCP

movement. These were relatively small businesses formed by a self-selecting group of skilled craftsmen and embodying their ideal of workers control. In 1945, even an advocate of workers' control, GDH Cole, would conclude:

Industrial Co-operation among producers exists in Great Britain only as an adjunct to the Consumers' Movement, on which it entirely depends... The Producers' Societies are not suited to mass-production of cheap lines, as they attract a type of labour keenly interested in craftsmanship and inimical to the discipline of the large factory turning out highly standardised products. ${ }^{69}$

Women shoe workers also played little part in this early NUBSO vision. The Equity Board in 1929 included 10 men and 1 woman; in 1986 the ratio was 9 to 2. Alice Hawkins (1863-1946) was an Equity NUBSO activist, but in 1911 she became President of the breakaway Independent National Union of Boot and Shoe Women Workers. ${ }^{70}$ Moreover, as Kirkham demonstrates for Equity, time and growing size eventually diffused the original idealistic impetus for workers control, as the experience of employee voice became less distinct from other good, unionised employers. ${ }^{71}$ The experimental golden age of COCP, in production and housing, was before the First World War. And the movement's Victorian model hardly seemed an adequate response to the urgent, large-scale reconstruction of industries and communities after the Second World War. ${ }^{72}$

All this said; here was an innovative, small-scale movement for industrial democracy, created, owned and partly run by their working class members. And while the COCP experience does demonstrate the importance of support from a wider institutional network - in this case, the consumer co-operative movement - it also suggests that even within a market economy, wellmotived and self-selected groups of skilled workers could create sustainable 'little utopias'. 
As Schumacher argues, 'people can be themselves only in small comprehensible groups' and perhaps size became part of the later participation problem at Equity. ${ }^{73}$ Most footwear workers probably didn't expect this level of engagement from their day job. For them including Leicester CWS employees and subsequent generations of COCP employees workers control was neither practicable nor desirable. They gained what employment protection they needed from the industry's strong twentieth century pluralist system of collective bargaining. Early COCPs offered something more: a sense of ownership and independence; and valued fraternity and local community over state-imposed equality. ${ }^{74}$ While never a formula for the replacement of capitalism as a system, as Robert Owen might have hoped, they were valuable additions to the voluntary civil society that lies between private business and the state in a true mixed economy. In that sense, they represent a blend of ethical socialist and radical-liberal ideals that transcend their time.

Both Lancaster and Walton recognise the appeal of all versions of co-operation to skilled, independent working men. However, they play-down the radical-liberal and nonconformist legacy of collective self-help, enshrined in the name of one COCP, by stressing the role of heterodox religion, secularism and socialism. ${ }^{75}$ There is no doubt that these all played a part in 1840s Rochdale and 1890s Leicester. But there is a danger of hurrying the working classes towards some early twentieth century breach with the values of radical-liberalism and religious non-conformity - as would befit Marx's socialist proletariat. Thus Pollard once spoke of voluntary co-operative socialism as 'pie in the sky' when faced with, 'the consciousness of the inevitable common interests of the working people as a class' ${ }^{76}$ Our pen portrait of these humble COCPs takes us away from such abstractions to presents a more complex, grounded picture of real, flesh-and-blood English working people trying to improve their world and drawing ideas from a much older radical tradition than socialism. The two 
key figures, Taylor and Mann, belonged to a religious sect, the Churches of Christ, but they were orthodox, nay fundamentalist, Christians, far removed from the free-thinking liberal Congregationalists who created Letchworth and Welwyn Garden Cities. ${ }^{77}$ As we have seen, Anchor was shaped more by radical- liberal social philosophy and conservative religious values. Yet,

The principles of the Church and of co-operation were highly compatible, not least in their democratic constitution, belief in self-denial and the upholding of a high moral tone. ${ }^{78}$

There is little evidence that any of the businesses were undermined by the sort of problems anticipated by the Webbs, such as weak, indecisive management, overbearing workers, or industrial relations conflict. Indeed, with the exception of an early and transient reluctance to introduce new technology at some co-operatives (but not all), the evidence suggests good quality, highly stable management, market-conscious workers prepared to endure lean years to keep their ideal going, and remarkably pacific industrial relations, albeit in an industry characterised by what Goodman el al termed 'rule-making and industrial peace'. ${ }^{79}$ Instead, when COCPs failed, they did so for conventional business reasons, including inadequate capital, over dependence on certain markets, and above all the general decline of both consumer co-operative sourcing and the British boot and shoe industry. From a peak of $11 \%$ of total British retail in 1958, consumer co-operation fell to $4 \%$, leaving the once triumphant consumer model in crisis too. ${ }^{80}$ And average COCP longevity was about seventy years - as long as Soviet Communism; and longer than most British nationalized industries!

On the social mission side, the Webb's misgivings appear largely mistaken. All the societies offered higher levels of worker participation than the average footwear firm or the CWS works in Leicester, and most were run by a management committee of mainly worker representatives. They supported the union closed shop and adhered to union agreements, even 
before these became the norm in the industry. In the village societies, COCPs carried union wages and conditions and labour movement values into the rural outposts. The educational work of all the societies was another distinctive feature, while Anchor made a contribution well beyond the workplace through a remarkable COCP housing initiative. Only the largest, most enlightened capitalist employers attempted similar projects, and many of these on a much more paternalist basis. Yet by 1958, the NUBSO historian, Alan Fox could say:

The rank-and-file attitudes towards the ideals and possibilities of co-operative production cooperative production, which could once be relied on to stir the hearts and minds of at least a few, can now only be described as one of complete indifference. The subject has never been raised in relation to practical policy during the post-war period. ${ }^{81}$

So why did COCP run out of steam as a movement and fail to rejuvenate? One answer, Fox's own at the time, was that the pragmatic liberal-pluralism of stable collective bargaining had usurped COCP radical-liberalism. And Kirkham notes the general tendency of workers control to atrophy, calling for a 'constant struggle' against oligarchical tendencies. ${ }^{82}$ Yet beyond industrial relations, the COCP model suffered a double ideological defeat. First, worker co-operation lost its once central place in the vision of a 'co-operative commonwealth', as that movement entered the twentieth century, notwithstanding the good relations that continued in Leicester. Second, after the First World War, big, top-down, statesocialist solutions, such as the welfare state, nationalization and council housing, marginalized initiatives taken from below by the working classes themselves. Anchor housing suffered the indignity of having its community areas compulsorily purchased by a local authority, which had once endorsed its vision. Thus the Webbs' prediction became a selffulfilling prophecy - a mark of Cain. For McKibbin, the collapse of the 1931 Labour Government 'represented the failure of the autodidact tradition in British politics'. ${ }^{83}$ Certainly, during the 1930 s, the entire co-operative movement lost the argument for more diverse and voluntary, bottom-up alternatives. ${ }^{84}$ And, as the Webbs had hoped, the early 
twentieth century age of working class autodidacts, like Taylor and Mann, gave way to the world of the professional CWS managers and state-socialist social engineers; working in the best interests of the working class, of course. By contrast, the Christian socialists and liberalradicals had 'upheld the cause of the common labouring man' ${ }^{85}$ And even today, as Wilson et al conclude for co-operation in general, the need for a:

"Big Society" of mutual, co-operatives, and similar enterprises, is neither isolated to the British isles not likely to be a passing fad. ${ }^{86}$

\section{Notes on contributor}

Peter Ackers is a research Professor of Employment Relations in the Department of HRM, Montfort University, Leicester and Visiting Professor of Labour and Social History at Loughborough University, both UK. His 'Gramsci at the Miners' Strike' appeared in Labor History, 2014. In 2015, Stewart Johnstone and Peter edited, Finding a Voice at Work? (Oxford University Press). A new edited historical collection with Alastair Reid, Alternatives to State-Socialism in Britain (Palgrave) appears in 2016. Peter is conducting a Biographical study of Professor Hugh Clegg and the 'Oxford School of Industrial Relations'. During the 2016/17 academic year he will be a Visiting Scholar at the Oxford Centre for Life Writing, Wolfson College.

\footnotetext{
${ }^{1}$ The National Co-operative Archive, Manchester holds most material, including Cooperative Directory, Co-operative Production, The Co-operative Productive Review, The Cooperative Official, The Co-operative Review.

2 See Burchill, Co-op, 102-106. Even the 'Rochdale Pioneers' (50-54), iconic founders of consumer co-operation and the 'dividend', had five original aims: a retail store, housing, production, a farm and a community - and pursued the first three. See Reeves too, Century of Rochdale Co-operation, 40-4.

${ }^{3}$ See Ackers, 'An Industrial Relations Perspective', 72 and 55-57 for a potted discussion of COCP, 55-57, which overlaps with this article; and Ackers and Reid, Alternatives to StateSocialism in Britain, Chapters 1 and 12, plus Chapter 3, Vorberg-Rugh and Whitecross, 'The Co-operative Party'.

${ }^{4}$ Wilson, Building Co-operation, 44-46.

${ }^{5}$ Summarised in Howles, Leicester; Birchall Co-op, 102-107.

${ }^{6}$ Birchall, Co-op, 106. See Potter, The Co-operative Movement and Webb and Webb, The Consumers' Co-operative Movement; and Wilson, Building Co-operation, 71-73.
} 
${ }^{7}$ For Marxist scepticism, see Ackers, 'An Industrial Relations Perspective', 64-66.

${ }^{8}$ Harrison, Sydney and Beatrice Webb, 177, 199-200, 163,

${ }^{9}$ Jones, British Producer Co-operatives, 43-45.

${ }^{10} \mathrm{Webb}$ and Webb, The Consumers Co-operative Movement, 29.

${ }^{11}$ Potter, The Co-operative Movement, 156. See: Bamfield, 'Co-operative Performance' ; Markey, 'Worker Directors'; Perotin, 'The Performance of Workers' Co-operatives?'; and Toms, 'Producer Co-operatives'.

12 Jones, British Producer Co-operatives, 52

${ }^{13}$ See Robertson, The Co-operative Movement.

${ }^{14}$ See Lancaster, Radicalism, Co-operation and Socialism, 134-149. Other local material below is from the Leicestershire and Rutland Record Office.

${ }^{15}$ Howles, Leicester, 322 . .

${ }^{16}$ Lancaster, Radicalism, Co-operation and Socialism, 93, 134; and Fox, A History, 182-86.

${ }^{17}$ Hoskins, 'Footwear Manufacture', 317-322; Hogg, 'Footwear Manufacturing', 314-326. .

${ }^{18}$ Greening, Distributive Co-operation, 101-2, 60.

${ }^{19}$ Lancaster, Radicalism, Co-operation and Socialism, 93.

${ }^{20}$ Wilson, Building Co-operation, 107-8, 122-5.

${ }^{21}$ Howles, Leicester, 322.

${ }^{22}$ Lancaster, Radicalism, Co-operation and Socialism, 63, 45, xxi-xxii.

${ }^{23}$ Fox, A History, 193; Goodman, Rule-making and Industrial Peace.

${ }^{24}$ Reid, A. J. and Biagini, E.F. (eds), Currents of Radicalism, Chapter 1.

${ }^{25}$ Newitt, The Who's Who of Radical Leicester. See for Mann and Taylor also the MacMillan Dictionary of Labour Biography (DLB) and for Greening, Holyoake and Vivian, the Oxford Dictionary of National Biography (ODNB)

${ }^{26}$ Chapter 11 of Holyoake, The Co-operative Movement, is titled (critically) 'The Song of State Socialism'.

${ }^{27}$ Lancaster, Radicalism, Co-operation and Socialism, 143-4.

${ }^{28}$ Figures from Mann, Democracy in Industry, 24-25, and Fox, A History, 187.

${ }^{29}$ Jones, British Producer Co-operatives, 53.

${ }^{30}$ Cole, A Century of Co-operation, 394-95.

${ }^{31}$ The histories are Greening, Pioneering Co-operation; Plumb, 50 Years of Equity; Kirkham, Industrial Producer Co-operation, Chapter 2; and Pepper, 100 years of Equity. See also Greening, Distributive Co-operation, 101-2; Howles, Leicester, 323; Lancaster, Radicalism, Co-operation and Socialism, 140-1. Equity records are held by Leicestershire and Rutland, Record Office.

${ }^{32}$ Lancaster, Radicalism, Co-operation and Socialism, 140-1.

${ }^{33}$ Webb, C., Industrial Co-operation, 134.

${ }^{34}$ See Gosling, 'Loss of Equity'.

${ }^{35}$ Greening, Distributive Co-operation in Leicester, 126.

${ }^{36}$ Howles, Leicester, 323.

${ }^{37}$ Plumb, 50 years of Equity, 12, 94.

${ }^{38}$ Kirkham, Industrial Producer Co-operation, 63.

${ }^{39}$ Pepper, 100 years of Equity, 3.

${ }^{40}$ Mann, Democracy in Industry, 44.

${ }^{41}$ Mann, Democracy in Industry; Howles, Leicester 1927, 325; and Leicester Co-operative Congress, Leicester, 210-13

${ }^{42}$ Mann, Democracy in Industry, 9.

${ }^{43}$ Greening, Distributive Co-operation in Leicester, 134.

${ }^{44}$ Carr-Saunders, Consumer Co-operation, 192. 
${ }^{45}$ Howles, Leicester, 325.

${ }^{46}$ Greening, Distributive Co-operation in Leicester, 134.

${ }^{47}$ Labour Prime Minister, 1924/5 and 1929/31 when he formed a National Government.

${ }^{48}$ Mann, Democracy in Industry, 57.

${ }^{49}$ Forrester, Humberstone Garden Suburb, 10.

${ }^{50}$ Birchall, 'Co-partnership Housing', 337-339 Table 1, 341-2.

${ }^{51}$ James, 'John Sutton Nettlefold'.

${ }^{52}$ Mann, Democracy in Industry; Newitt, The Who's Who of Radical Leicester.

${ }^{53}$ Birchall, 'Co-partnership Housing', 348.

${ }^{54}$ Forrester, Humberstone Garden Suburb, 18, 27, 57.

${ }^{55} \mathrm{M}$. Tims quoted in Birchall, 'Co-partnership Housing', 351.

${ }^{56}$ See Ackers and Black, 'Paternalist Capitalism'; and Ackers, P., 'On Paternalism'.

${ }^{57}$ Leicester Co-operative Congress, Leicester, 213-15. See also Greening, Distributive Cooperation in Leicester, 160; and Howles, Leicester, 325-326. Self-Help records are held by Leicestershire and Rutland, Record Office.

${ }^{58}$ Anon, Boot and Shoe Factories of Barwell. See too: Leicester Co-operative Congress, Leicester, 220-23; Howles, Leicester 1927, 326; and Anon, A Short History, which doesn't mention Sperope. There are minor differences of date and location between the accounts.

${ }^{59}$ Howles, Leicester 1927, 326.

${ }^{60}$ Howles Leicester 1927, 326; and see Leicester Co-operative Congress, Leicester, 222-23;

Halstead, The Story of a village industrial democracy; Wilshire, Glenfield, 15.

${ }^{61}$ Leicester Co-operative Congress, Leicester, 222-23.

${ }^{62}$ Leicester Co-operative Congress, Leicester, 223.

${ }^{63}$ Howles Leicester 1927, 326

${ }^{64}$ Howles, Leicester, 1927, 326; and see: Martin, Sileby and District, 9; Leicester Cooperative Congress, Leicester, 225-26.

${ }^{65}$ Leicester Co-operative Congress, Leicester, 225.

${ }^{66}$ Leicester Co-operative Congress, Leicester, 226.

${ }^{67}$ Anon, Sileby Trade Unons: Interviewed 1980.

${ }^{68}$ Fox, History and Heritage, xi.

${ }^{69}$ Cole, A Century of Co-operation, 394-96.

${ }^{70}$ Pepper, 100 years of Equity; Newitt, The Who's Who of Radical Leicester.

${ }^{71}$ See Johnstone and Ackers, Finding a Voice at Work?

${ }^{72}$ Ackers, and Payne, 'Before the Storm'.

${ }^{73}$ Schumacher, Small is Beautiful, 62.

${ }^{74}$ Birchall, Co-op, 344.

${ }^{75}$ Lancaster, Radicalism, Co-operation and Socialism; Walton, 'Revisiting the Rochdale Pioneers'.

${ }^{76}$ Pollard, 'The Foundation of the Co-operative Party', 191.

${ }^{77}$ Ackers, 'West End Chapel, Back Street Bethel' and 'The Churches of Christ as a Labour Sect'; Binfield, C., 'Garden City Religion'.

${ }^{78}$ Forrester, Humberstone Garden Suburb, 123.

${ }^{79}$ Goodman, Rule-making and Industrial Peace.

${ }^{80}$ Birchall, Co-op, 136-7, 163, 190.

${ }^{81}$ Fox, A History, 637.

${ }^{82}$ Kirkham, Industrial Producer Co-operation, 189.

${ }^{83}$ McKibbon, Parties and People, 84.

${ }^{84}$ Vorberg-Rugh and Whitecross, 'The Co-operative Party'.

${ }^{85}$ Backstrom, Christian Socialism, 8. 
${ }^{86}$ Wilson, Building Co-operation, 396.

\section{References}

Ackers, P., 'West End Chapel, Back Street Bethel: Labour and Capital in the Wigan Churches of Christ c 1845-1945', The Journal of Ecclesiastical History, 47(2), April 1996, 298-329.

Ackers, P., 'On Paternalism: Seven Observations on the Uses and Abuses of the Concept in Industrial Relations, Past and Present', Historical Studies in Industrial Relations, 6, Spring, 1998, 173-193.

Ackers, P., 'Taylor, John Thomas (1863-1958)' and 'The Churches of Christ as a Labour Sect, Special Note', in Dictionary of Labour Biography, X, Bellamy, J.M. and Saville, J. (eds), MacMillan, 2000, 195-206.

Ackers, P., 'Reframing Employment Relations: The Case for Neo-Pluralism', Industrial Relations Journal, 33(1), 2002, 2-19.

Ackers, P. and Payne, J., 'Before the Storm: The Experience of Nationalization and the Prospects for Industrial Relations Partnership in the British Coal Industry, 1947-1972 Rethinking the Militant Narrative', Social History, 27(2), May 2002, 184-209.

Ackers, P., 'Collective bargaining as Industrial Democracy: Hugh Clegg and the Political Foundations of British Industrial Relations Pluralism', British Journal of Industrial Relations, 45:1, 2007, March, 77-102.

Ackers, P., 'An Industrial Relations Perspective on Employee Participation', in Wilkinson, A., Gollan, P.J, Marchington, M., and Lewin, D., (eds) The Oxford Handbook of Participation in Organizations, Oxford University Press, 2010.

Ackers, P. and Black, J., 'Paternalist Capitalism: An Organisation Culture in Transition', in Work and the Enterprise Culture, edited by M. Cross and G. Payne, London: Falmer/ BSA, 1991, 30-56.

Ackers P. and Reid, A.J., (eds) Alternatives to State-Socialism in Britain: Other Worlds of Labour in the Twentieth Century, London: Palgrave, 2016 (forthcoming).

Anon, 'Boot and Shoe Factories of Barwell', on-line.

Anon, A Short History of the Barwell and District Co-operative Society Ltd, 1871-1921, Manchester: CWS Printing, 1921.

Anon, Sileby Trade Unions, on-line

Backstrom, P.N., Christian Socialism and Co-operation in Victorian England: Edward Vansittart Neale and the Co-operative Movement, London: Croome Helm, 1974.

Binfield, C., 'Garden City Religion: the Free Churches of Letchworth and Welwyn', in The Chapels Society Journal, Volume 2, 2016: 58-91.

Burchall, J., Co-op: the people's business, Manchester University Press, 1994.

Burchall, J., 'Co-partnership and the garden city movement', in Planning Perspectives, 10, 1995: 329-358.

Carr-Saunders, A.M., Sargent, F.P. and Peers, R., Consumer Co-operation in Great Britain. London: Allen and Unwin, 1938.

Cole, G.D.H., A Century of Co-operation, London: Allen and Unwin, 1945.

Forrester, M.D., 'An Examination of the Origins and Sources of Humberstone Garden Suburb, Leicester (1907-1914), MA Dissertation, Leicester Polytechnic, 1984.

Fox, A., A History of the National Union of Boot and Shoe Operatives, 1874-1957, Oxford: Blackwell, 1958.

Fox, A., History \& Heritage: The Social Origins of the British Industrial Relations System, London: Allen and Unwin, 1985.

Goodman J.F.B., et al, Rule-making and Industrial Peace, London: Croom Helm, 1977. Gosling, P., 'Loss of Equity in co-op movement', Co-operative News, February 2, 2009. 
Greening, E.O., Distributive Co-operation in Leicester, Leicester Co-operative Printing Society, 1898.

Greening, E.O., A Pioneer Co-partnership: Being the History of the Leicester Co-operative Boot and Shoe Manufacturing Society Ltd, Leicester Co-operative Society, 1923.

Halstead, R., The Story of a village industrial democracy: Being 21 years history of the Glenfield 'Progress' Co-operative Boot and Shoe Manufacturing Society Ltd, Leicester Cooperative Society, 1914.

McKibbon, R., Parties and People: England 1914-1951, Oxford University Press, 2010. Harrison, J.F.C., Robert Owen and the Owenites in Britain and America: The Quest for a New Moral Order, London: Routledge, 1969.

Harrison, R.J., The Life and Time of Sydney and Beatrice Webb, 1958-1905: The Formative Years, London: Palgrave, 2000.

Hogg, V.W., 'Footwear Manufacture', pp. 314-326 in R.A. McKinley (ed.), A History of the Country of Leicester, Vol. 4 Victoria Country History, Oxford University Press, 1958.

Holyoake, G.J., The Co-operative Movement Today, London: Methuen: 1903.

Holyoake, G.J., The History of Co-operation, London: Unwin, 1903.

Howles, C., Leicester: Its Civic, industrial, Institutional and Social Life, Midland Service Agencies, Ltd. 1927.

Hoskins, W.G., 'Footwear', pp. 23-25 in W.G. Hoskins and R.A. McKinley (eds.) A History of the County of Leicester, Vol. 3 Victoria County History, Oxford University Press, 1955. Jones, D.C., British Producer Co-operatives, in K. Coates (ed.), The New Worker Cooperatives, Nottingham: Spokesman: 1976.

Johnstone, S. \& Ackers, P. (eds) Finding a Voice at Work? New Perspectives on Employment Relations, Oxford University Press, February 2015.

Kirkham, J., Industrial Producer Co-operation in Great Britain: Three case studies, University of Sheffield, MA Dissertation, 1973.

Lancaster, B. Radicalism, Co-operation and Socialism: Leicester Working Class Politics, 1860-1906, Leicester University Press, 1987.

Leicester Co-operative Congress, Leicester: A Souvenir of the Forty-Seventh Co-operative Congress, CWS, 1915.

Mann, A., Democracy in Industry: The Story of Twenty-One Years Work of the Leicester Anchor Boot and Shoe Productive Society Limited, Leicester Co-operative Printing Society Limited, 1914.

Markey, R., Balnave, N., and Patmore, G. 'Worker Directors and Worker Ownership/ Cooperatives', in The Oxford Handbook of Participation in Organizations, Oxford University Press, 2010.

Martin, D., A Historical Study of Sileby and District, Sileby: Townswomen's Guild Social Studies Group, 1966.

Newitt, N., The Who's Who of Radical Leicester: http://www.nednewitt.com/whoswho/

Pawson, I. Anchor Tenants Limited: A Brief History:

http://www.anchortenants.org/booklet/brief history.pdf

Pepper, S.W., 100 Year of Equity: A History of Equity Shoes Limited, Company, Leicester, 1986.

Perotin, V., 'The Performance of Workers' Co-operatives?', in The Cooperative Business Movement, 1950 to the Presented, edited by P. Battilani and H. Schroeter (eds), New York: Cambridge University Press, 2012, 195-221.

Plumb, J.H., 50 Years of "Equity" shoemaking: The History of the Leicester Co-operative Boot and Shoe Manufacturing Society Ltd, Leicester Co-operative Society, 1936. 
Pollard, S., 'Nineteenth-century co-operation: From community building to shopkeeping, in Essays in Labour History, Vol. 1, edited by A. Briggs and J. Saville, London: MacMillan, 1960: 74-112.

Pollard, S., 'The Foundation of the Co-operative Party', in Essays in Labour History, Vol. 2, edited by A. Briggs and J. Saville, London: MacMillan, 1971, 185-210.

Potter, B., The Co-operative Movement in Great Britain, London: Swan Sonneneschein, 1895.

Reeves, J., Century of Rochdale Co-operation, 1844-1944, London: Lawrence and Wishart, 1944.

Reid, A. J. and Biagini, E.F., (eds), Currents of Radicalism: Popular radicalism, organised labour and party politics in Britain, 1850-1914, Cambridge University Press, 1991.

Robertson, N., The Co-operative Movement and Communities in Britain, 1914-1960: Minding Their Own Business, Farnham: Ashgate, 2010.

Schumacher, E.F., Small is Beautiful, London: Abacus 1974.

Toms, S., 'Producer Co-operatives and Economic Efficiency: Evidence from the NineteenthCentury Cotton Textile Industry, Business History, 54/6, 2012, 855-82.

Turner, K., (ed) Humberstone: As I Remember It, Leicestershire Libraries, 1991.

Vorberg-Rugh R. and Whitecross, A., 'The Co-operative Party: an alternative vision of social ownership', in Ackers P. and Reid, A.J., (eds) Alternatives to State-Socialism in Britain:

Other Worlds of Labour in the Twentieth Century, London: Palgrave.

Walton, J.K., 'Revisiting the Rochdale Pioneers', Labour History Review, 80 (3) 215-247.

Webb, C., Industrial Co-operation: The Story of a Peaceful Revolution, Co-operative Union, 1904.

Webb, S. and Webb, B., The Consumers' Co-operative Movement, London: Longmans, Green and Co. 1921.

Wilshire, J., Glenfield: A Considerable Village, Leicester Research Services, Chamberlain Music and Books, 1971/ 1984.

Wilson, J.F., Webster, A. and Vorberg-Rugh, R., Building Co-operation: A Business History of the Co-operative, Oxford University Press, 2013.

Table 1: Producer Co-operation in England and Wales* 


\begin{tabular}{|l|l|l|l|l|}
\hline & TOTAL & SHOE & LEICS & LEICS SHOE \\
\hline 1922 & 99 & $19(1)$ & 11 & 6 \\
\hline 1932 & 88 & $18(0)$ & 9 & 7 \\
\hline 1940 & 84 & $14(7)$ & 8 & 5 \\
\hline 1951 & 42 & $16(0)$ & 12 & 6 \\
\hline 1957 & 31 & $12(0)$ & 8 & 4 \\
\hline
\end{tabular}

Source: Co-operative Directory, Brackets = shoe repair. From 1951 this only lists 'Members of the Co-operative Productive Federation' which may partly account for the sudden collapse.

Table 2: The main Leicestershire Co-partnership Footwear Productive Societies

\begin{tabular}{|l|l|l|l|l|l|}
\hline $\begin{array}{l}\text { NAME \& } \\
\text { YEAR OF } \\
\text { FOUNDATION }\end{array}$ & \multicolumn{5}{|c|}{ MEMBERSHIP } \\
\hline & 1922 & 1932 & 1940 & 1951 & 1957 \\
\hline $\begin{array}{l}\text { Leicester } \\
\text { Equity (1887) }\end{array}$ & 1130 & 1113 & 1255 & 1571 & 1595 \\
\hline $\begin{array}{l}\text { Barwell } \\
\text { Sperope } \\
(1891)\end{array}$ & 271 & $?$ & 307 & 320 & 306 \\
\hline $\begin{array}{l}\text { Glenfield } \\
\text { Progress } \\
(1892)\end{array}$ & 303 & 315 & 285 & 227 & 233 \\
\hline $\begin{array}{l}\text { Leicester } \\
\text { Anchor (1893) }\end{array}$ & 652 & 635 & - & - & - \\
\hline $\begin{array}{l}\text { Leicester Self- } \\
\text { Help (1896) }\end{array}$ & 288 & 232 & 218 & 228 & 266 \\
\hline $\begin{array}{l}\text { Sileby } \\
\text { Excelsior } \\
(1907)\end{array}$ & 121 & 150 & 150 & 178 & 191 \\
\hline
\end{tabular}

Source: Co-operative Directory 